This item was submitted to Loughborough's Research Repository by the author.

Items in Figshare are protected by copyright, with all rights reserved, unless otherwise indicated.

\title{
On the duration of sovereign ratings cycle phases
}

\section{PLEASE CITE THE PUBLISHED VERSION}

https://doi.org/10.1016/j.jebo.2019.01.016

\section{PUBLISHER}

(c) Elsevier

\section{VERSION}

AM (Accepted Manuscript)

\section{PUBLISHER STATEMENT}

This paper was accepted for publication in the journal Journal of Economic Behavior and Organization and the definitive published version is available at https://doi.org/10.1016/j.jebo.2019.01.016

\section{LICENCE}

CC BY-NC-ND 4.0

\section{REPOSITORY RECORD}

Agnello, Luca, Vitor Castro, and Ricardo M. Sousa. 2019. "On the Duration of Sovereign Ratings Cycle Phases". Loughborough University. https://hdl.handle.net/2134/36831. 


\title{
On the Duration of
}

\section{Sovereign Ratings Cycle Phases*}

Luca Agnello ${ }^{\dagger}$
Vitor Castro

\author{
Ricardo M. Sousa ${ }^{\S}$
}

\begin{abstract}
Using long-term sovereign ratings data for a panel of 130 countries over the last three decades, we investigate the duration and determinants of sovereign rating phases through the lens of discrete-time Weibull models. We find that the likelihood of the end of the 'speculative-grade' phase increases as time goes by (i.e. there is positive duration dependence), but the 'investment-grade' phase is not duration dependent. Thus, for sovereigns rated as speculative, the build-up of reputation as good borrowers is a gradual process, whereas the reputation of investment-grade sovereigns solidifies and remains unchanged as time passes. However, the length of both phases significantly depends on the country's economic conditions. In particular, lower inflation, stronger growth and sounder fiscal policies shorten (prolong) the speculative- (investment-) grade phase. In addition, better governance quality helps to reduce the duration of speculative-grade phases.
\end{abstract}

Keywords: duration analysis, duration dependence, sovereign ratings, investment-grade, speculativegrade, economic environment, fiscal position, quality of governance.

JEL codes: G10, G15, G24, C23, C25.

\footnotetext{
* The views expressed in this paper are those of the authors and do not necessarily reflect those of the ESM or ESM policy. We are grateful to participants to the 5th International Symposium in Computational Economics and Finance (ISCEF), seminars and discussions at the Loughborough University and the University of Minho, and to Alan Kirman, Julien Chevallier, Gilles Dufrénot, Fredj Jawadi, Wael Louhichi, Stefan Lyocsa, Anders Rahbek and António Santos, for their constructive comments and suggestions that considerably improved this paper.

${ }^{\dagger}$ Corresponding author. University of Palermo, Faculty of Economics, Department of Economics, Business and Statistics, Viale delle Scienze, 90128 Palermo, Italy. Email: luca.agnello01@unipa.it.

Loughborough University, School of Business and Economics, Loughborough, Leicestershire LE11 3TU, United Kingdom; University of Minho, Economic Policies Research Unit (NIPE), Campus of Gualtar, 4710-057 - Braga, Portugal. Email: V.M.Q.Castro@lboro.ac.uk.

${ }^{\S}$ European Stability Mechanism (ESM), 6a Circuit de la Foire Internationale, L-1347 Luxembourg; University of Minho, Department of Economics and Economic Policies Research Unit (NIPE), Campus of Gualtar, 4710-057 - Braga, Portugal; University of Minho, Department of Economics and Economic Policies Research Unit (NIPE), Campus of Gualtar, 4710-057 - Braga, Portugal; London School of Economics and Political Science, LSE Alumni Association, Houghton Street, London WC2 2AE, United Kingdom. E-mails: r.sousa@esm.europa.eu,rjsousa@eeg.uminho.pt, rjsousa@alumni.lse.ac.uk. NIPE's work is carried out within the funding with COMPETE reference $n^{\circ}$ POCI-01-0145-FEDER-006683, with the FCT/MEC's (Fundação para a Ciência e Tecnologia, I.P.) financial support through national funding and by the ERDF through the Operational Programme on "Competitiveness and Internationalization COMPETE 2020" under the PT2020 Partnership Agreement. This research was undertaken before Ricardo Sousa joined the ESM.
} 


\section{Introduction}

Credit rating agencies (CRAs) play a crucial role in the development of financial markets. By publishing information on the ability of entities (such as, banks, firms and sovereigns) to meet their financial obligations, CRAs contribute to the correction of market failures caused by asymmetric information between lenders and borrowers.

Updates of credit risk ratings also influence market participants' behaviour with implications for international capital flows and borrowing costs. Hence, in response to new information provided by CRAs, capital can move away from 'risky' investments and towards 'high-grade' investments (i.e. the so-called 'flight to quality') and low-credit ratings entities pay higher interest rates than those with better credit standards.

On the one hand, the reporting activity of CRAs stimulate borrowers to pursue sounder financial and economic policies aimed at enhancing their capability to access international capital markets (Agnello et al., 2018a). On the other hand, it could inadvertently destabilize financial markets and generate spillover effects. ${ }^{1}$

These concerns emerged dramatically during the euro area sovereign debt crisis, when the financial stress faced by countries like Greece, Ireland and Portugal spilled to other EU countries leading to a significant rise in sovereign bond yield spreads. ${ }^{2}$ In this context, CRAs were often blamed for being somewhat pro-cyclical in their ratings assessments, thus, potentially exacerbating contagion (Michaelides et al., 2015). ${ }^{3}$

These episodes have revived the interest among academics and practitioners on the behaviour of sovereign credit ratings and their impact on global financial markets. In particular, the opacity of the methodology underlying the determination of sovereign ratings led many authors to empirically assess their main drivers. ${ }^{4,5}$

\footnotetext{
${ }^{1}$ Duggar et al. (2009) analyse crises in Indonesia (1997-2002), Russia (1998-1999) and Argentina (20012002 ), and find that $61 \%$ of default episodes by rated corporations occurred during sovereign crises. Mallick and Mostak Ahamed (2017a, 2017b, 2017c) highlight that excessive risk-taking can cause disruptions on financial stability.

${ }^{2}$ After Lehman Brothers' bankruptcy, the world economy witnessed: (i) large wealth effects and abrupt market sentiment shifts (Granville and Mallick, 2009; Jawadi et al., 2018); (ii) the strong inter-connection between monetary, fiscal and financial stability (Agnello et al., 2012; Castro and Sousa, 2012; Jawadi et al., 2018); (iii) a somewhat business cycle de-synchronization (Castro, 2010; Mallick and Mohsin, 2010, 2016); (iv) the sharp sovereign debt rise and subsequent fiscal consolidation implementation (Jalles, 2018); and (v) and a substantial total factor productivity (TFP) slowdown (Jalles, 2015).

${ }^{3}$ After downgrading sovereign debt of Greece, Portugal and Ireland, CRAs also downgraded other Eurozone countries (e.g. France and Austria). This was linked with an increase in yield spreads and contributed to self-fulfilling prophecies about debt repayment abilities (Aizenman et al., 2013).

${ }^{4}$ Credit Rating agencies underline that they do not use a specific formula to combine the various political and economic factors in deciding on a specific rating.

${ }^{5}$ See, for instance, Cantor and Packer (1996), Juttner and McCarthy (1998), Ferri et al. (1999), Kaminsky and Schmukler (2002), Sy (2002), Mora (2006), Hu et al. (2002) and Broto and Molina (2016).
} 
Yet, the existing works leave some relevant questions about an important dimension of sovereign ratings open: Does the likelihood of exiting a specific phase increase or decrease as time goes by? What are the determinants of the duration of sovereign rating phases? How do economic developments and the quality of institutions influence the length of sovereign rating phases?

To address these questions, we follow a three-step strategy. First, we consider the history of long-term sovereign ratings for a sample of 130 developed and emerging economies over the last three decades. Thus, we rely on the identification of 'speculative-grade' and 'investment-grade' using Fitch's convention to construct phases (or spells of time) over which sovereign issuers have been given a specific rating (risk) class. Second, we consider a set of macroeconomic and qualitative indicators, which are expected to affect the duration of sovereign rating phases. Third, we estimate discretetime Weibull duration models to test for the presence of duration dependence and identify those variables influencing the length of each sovereign ratings phase.

Our main empirical findings can be summarised as follows. We show that sovereign credit rating phases are characterised by significant differences in their duration dependence. In particular, the likelihood of a speculative-grade phase' ending increases as time goes by (i.e. there is positive duration dependence), while the investment-grade phase is not duration dependent. This is consistent with the idea that "time" matters for the build-up of reputation and the view that sovereign ratings exhibit greater stability at higher ratings levels than at lower ratings.

Concerning the role played by economic and institutional factors in determining the length of sovereign rating phases, we find that lower inflation, better economic performance and sounder fiscal positions shorten (protract) the speculative(investment-) grade phases.

Interestingly, we also show that the quality of governance plays a key role. In particular, for sovereigns experiencing a speculative-grade phase, an improvement in governance quality can help to accelerate their ratings upgrade, especially in the case of sovereign debt denominated in foreign currency. For instance, in the case of (domestic-) foreign currency-denominated debt, a one point rise in the composite index of governance quality increases the probability of a speculative-grade ratings phase ending by, approximately, (25\%) 39\%. By contrast, institutional factors are, from a statistical point of view, much less important for the duration of sovereigns' investment-grade 
spells, which reflects the fact that these countries are typically developed and already benefit from a strong institutional framework.

In addition, being part of OECD group of countries is associated with a lower probability that an investment-grade phase ends. The length of the speculative-grade phase is also shorter for advanced economies than for emerging markets.

Finally, while the evidence uncovered in this paper suggests some quadratic behaviour for speculative-grade phases - with the likelihood of the end of this phase increasing over time for spells shorter than 11 years and decreasing afterwards -, the hazard rate associated with investment-grade phases does not display any nonmonotonic behaviour.

The rest of this paper is organised as follows. In Section 2, we present a brief review of the related literature. Section 3 details the econometric strategy. In Section 4, we describe the data. Section 5 discusses the empirical results, while Section 6 provides the sensitivity analysis. Finally, in Section 7, we conclude and draw the main policy implications.

\section{Literature Review}

There is a large body of the literature looking at the main drivers of sovereign ratings. Using cross-sectional data for 49 countries as of September 1995, Cantor and Packer (1996) find that sovereign ratings are generally consistent with economic fundaments. In particular, the estimates of a simple linear regression model indicate that their dynamics can largely be explained by variables, such as per capita income, GDP growth, inflation and external debt. The authors also show that sovereign ratings have an impact on sovereign bond spreads. More specifically, US Treasury bond spreads rise by 0.9 percentage points after negative rating announcements, and fall by 1.3 percentage points in the case of positive announcements. Sy (2002) also finds a negative correlation for emerging market bond spreads over the US Treasury bill rate.

Juttner and McCarthy (1998) extend the analysis by Cantor and Packer (1996), and examine the determinants of Moody's and S\&P's sovereign ratings for a range of mature and emerging market economies in the mid-1990s. They conclude that the linear relationship between the variables identified by Cantor and Packer (1996) and sovereign ratings was stable until 1997. After the outbreak of the Asian crisis, additional controls (such as the ratio of problematic bank assets over GDP and the interest rate differentials) seem to play a major role in explaining sovereign ratings. 
Using Moody's data for 17 countries, Ferri et al. (1999) find that, during the Asian crisis, credit ratings of East Asian countries behaved in a pro-cyclical way as a result of ratings downgrades more than macroeconomic fundamentals would justify. This, in turn, impacted market expectations and aggravated the crisis.

Other works draw similar conclusions on the pro-cyclical nature of sovereign ratings. For example, Kaminsky and Schmukler (2002) use a panel of 16 emerging markets including East Asian, Eastern European, and Latin American economies, and find that CRAs upgrade countries in good times and downgrade them in bad times. They also find that changes in sovereign ratings contribute to contagion and spillover effects, with rating changes among emerging markets triggering fluctuations in both yield spreads and stock returns in foreign countries. Mora (2006) revisits the results by Ferri et al. (1999) and reaches different conclusions. By extending the sample to the post-Asian crisis period from 1999 to 2001, the author finds that sovereign credit ratings are sticky rather than pro-cyclical and remained over-conservative after the crisis. In addition, the author finds that sovereign ratings react passively to market sentiment (as proxied by spreads) and are driven by political factors. Hu et al. (2002) rely on ordered probit models to assess the determinants of sovereign ratings and estimate the rating transition matrices. The empirical findings suggest that default history, lower reserves, higher inflation, higher debt to GNP ratio, being a non-industrial country and higher ratio of debt service to exports lower the quality of credit. Using a logit transformation of the numerical-rating scale, Alsakka and ap Gwilym (2013) find that exchange rates significantly respond to rating agencies' outlook and watch signal news, with market reactions being stronger during the last global financial crisis than in the run-up to it.

A recent study by Broto and Molina (2016) departs from the traditional empirical literature in that it focuses on the characteristics and determinants of sovereign rating 'cycles', instead of ratings per se. The authors assume that a credit cycle consists of two phases: 1) a 'downgrade' phase, where the rating goes from peak to trough; and an 'upgrade' phase, where the rating improves. Estimating logit and ordered models for a sample of 67 emerging and developed countries over the period 1994:Q12013:Q1, they show that rating cycles are characterised by strong asymmetry. More specifically, downgrade phases are shorter than upgrade phases, as rating agencies are faster at updating ratings in response to the economic recovery (during downgrade phases) and more prudent at revising ratings even in case of strong economic 
performance (during upgrade phases). Consequently, downgrade phases behave in a pro-cyclical way, whereas upgrade periods tend to be relatively sticky.

Our paper contributes to this strand of research on the determinants of sovereign rating phases. In this respect, it is inspired by the work of Broto and Molina (2016). Yet, from a conceptual point of view and an empirical perspective, it departs from existing studies in two main aspects. First, we pay close attention to the duration of sovereign rating phases rather than the occurrence of a particular rating change. From a policy perspective, this distinction is important because welfare implications can be quite different. For instance, the welfare losses due to a rating downgrade are relatively small if a (subsequent) upgrade takes place shortly afterwards. By contrast, welfare losses can be particularly high if the average duration of a (lower) rating class is long.

Second, we test for the presence of duration dependence, that is, we assess how time (i.e. own age) affects the length of sovereigns rating phases. From an operational point of view, this provides valuable information to market participants both about the timing of sovereign ratings revisions and, most importantly, the transition across different credit risk classes. To give some economic intuition, we highlight that the passage of time gives sovereigns the opportunity to build up and/or solidify their reputation as good or bad borrowers. If a certain sovereign seizes (misses) such opportunity, then, the probability of a rating upgrade increases (declines) over time. And, obviously, for sovereigns with an already fairly solidified reputation as excellent borrowers (e.g., AAA-rated sovereign bonds), we might even expect that the probability of exiting the investment-grade phase does not significantly change as time passes by. In this context, our results are in line with the spirit of the work by Alsakka and ap Gwilym (2010), who show that the informational content and the reputational effects are stronger in the case of negative credit announcements than positive ones.

\section{Econometric Methodology}

Following Agnello et al. (2013, 2015a, b, 2018a, b, c), we rely on the class of hazard-based duration models. ${ }^{6}$ Because of their properties, they are particularly wellsuited to test whether the likelihood of a sovereign rating phase ending depends (or not)

\footnotetext{
${ }^{6}$ For an analysis of: (i) the duration of business cycle phases and unemployment spells, see Kiefer (1988), Sichel (1991) and Castro (2010); (ii) duration dependence in stock market cycles, see Lunde and Timmermann (2004); (iii) the determinants of the length of housing booms and busts, see Agnello et al. (2018b); (iv) the duration of periods of financial markets' shutdown and re-access, see Agnello et al. (2018c); and (v) the drivers of the duration of fiscal consolidation, see Agnello et al. (2013).
} 
on its own age. Their applicability to discrete-time model specifications also accommodates external covariates.

To better understand the theoretical reasons behind the use of hazard models, we start by introducing two key concepts, namely: the hazard function and the survival functions. Let $T$ be a non-negative continuous random variable measuring the time span between the beginning of a sovereigns rating phase and the moment it ends with probability distribution $F(t)=\operatorname{Pr}(T<t)$, i.e. the probability of $T$ being smaller than a certain value $t$. Then, we can define the survival function at time $t, S(t)=\operatorname{Pr}(T \geq t)=1$ $F(t)$ as the probability that the duration of sovereign rating phase is at least equal to $t$. From this and the density function, $f(t)$, we get the hazard function at time $t$ as $h(t) ? f(t) / S(t)$. This function measures the conditional probability of a sovereign rating phase ending at time $t$ given that it lasted until to that point in time.

The shape of the hazard function has important implications for the duration dynamics. The proportional hazard model is one of most popular parametric forms for the hazard function, as it can accommodate the effect of time-varying covariates:

$$
h(t, x) ? h_{0}(t) \exp \left(\mathbf{x}^{\bullet}\right)
$$

where $h_{0}(t)$ is the baseline hazard, - is a $(\mathrm{k} \times 1)$ vector of parameters that need to be estimated and $\mathbf{x}$ is a vector of time-invariant covariates. We impose a specific parametric form for the function $h_{0}(t)$ using a Weibull model:

$$
h_{0}(t) ? \operatorname{lpt}^{p / 1},
$$

where $\gamma$ is a constant while $p$ is a non-negative parameter providing information about the nature of duration dependence. A value of $p$ greater (lower) than 1 indicates the existence of positive (negative) duration dependence. Positive (negative) duration dependence means that the likelihood of a sovereign rating phase ending increases (decreases) as the time goes by. If $p$ equal to one, there is no evidence of duration dependence. Replacing (2) into (1), we have:

$$
h(t, \mathbf{x}) ? \iota p t^{p / 1} \exp \left(\mathbf{x}^{\bullet}\right) .
$$

So far, we have assumed that the duration variable $T$ is continuous and the hazard function $h(t)$ varies on a continuous-time scale. Thus, $h(t)$ can be interpreted as the instantaneous probability that a sovereigns rating phase ends in an infinitesimally small time period $T$ after time $t$, given that the duration has not elapsed until time $t$. 
Nevertheless, from a practical point of view, data collected in our study are discrete and organised on yearly frequency basis. It follows that continuous-time duration models are not the most adequate to use (Allison, 1982).

However, their discretisation, as proposed by Prentice and Gloeckler (1978), Allison (1982), and Jenkins (1995), is viewed as a valid solution to the problem and is commonly used in the empirical literature. In addition, discrete-time duration models have the important advantage of allowing for the inclusion of time-varying covariates, therefore, allowing one to assess the main determinants of the duration of each phase.

Following Prentice and Gloeckler (1978), a discrete-time version of the proportional hazards model can be written as:

$$
\begin{gathered}
\left.P_{i t} ? \operatorname{Pr}\right] T_{i} ? t \mid T_{i} \geq t, \mathbf{x}_{i t} ? 1 / e^{/ h_{t} e^{\cdot x_{i t}}} ? 1 / e^{/ e^{v_{t} \cdot \cdot x_{i t}}} \\
\Leftrightarrow \ln ] / \ln \left(1 / P_{i t}\right)_{-} ? v_{t}-\cdot \mathbf{x}_{i t}
\end{gathered}
$$

which is equivalent to the complementary log-log (or cloglog) function, where $v_{t}\left(? \ln h_{t}\right)$ represents the logarithm of an unspecified (baseline hazard) function of time and $\mathbf{x}_{i t}$ is a vector of time-varying control variables. A popular specification for $v_{t}$ is the discrete-time analogue to the continuous-time Weibull model, which yields:

$$
v_{t} ? \ln h_{t} ? \chi-(p / 1) \ln t^{7}
$$

Prentice and Gloeckler (1978) and Allison (1982) show that discrete-time loglikelihood function for a sample of $i ? 1, \ldots, n$ spells can be written as follows:

$$
\ln L ? \sum_{i ? 1}^{n} \sum_{j ? 1}^{t_{i}} y_{i t} \ln \left(\frac{P_{i j}}{1 / P_{i j}}\right)-\sum_{i ? 1}^{n} \sum_{j ? 1}^{t_{i}} \ln \psi / P_{i j} \dagger,
$$

where the dummy variable $y_{i t}$ is equal to 1 if the end of a sovereign rating phase for a country $i$ ends at time $t$, and 0 otherwise. The model is estimated by Maximum Likelihood substituting $P_{i j}$ by (4) and $v_{t}$ by (5).

\footnotetext{
${ }^{7}$ As noted by Rodríguez (2010), in the continuous-time duration model formulation, there are alternative parametric forms for the distribution of survival time, including: (i) the exponential distribution; (ii) the Weibull distribution; (iii) the Gompertz-Makeham distribution; (iv) the gamma distribution; (v) the generalised Gamma distribution; (vi) the log-normal distribution; (vii) the log-logistic distribution; (viii) the generalised F distribution; and (ix) the Coale-McNeil model. For some of these parameterisations, the hazard function is monotonic (e.g., the Weibull); for others, the hazard function is non-monotonic (e.g., the log-logistic). In the case of discrete-time duration models, there are also some non-monotonic formulations of the baseline hazard function like polynomial-in-time and piecewise-dummies with one dummy for each duration $t$ or group of durations/intervals (Jenkins, 2005; Agnello et al., 2013; Castro and Martins, 2013). Despite this, the use of dummy variables is problematic, as the estimated hazard function may lack a clear pattern, which complicates the interpretation of results. In this context, Beck et al. (1998) recommend the use of "natural cubic splines". In Section 6.2., we provide evidence with nonmonotonic specifications for the hazard function.
} 


\section{Data}

We use a sample of 130 industrialized and emerging countries for which longterm sovereign ratings are reported by Fitch Ratings Inc. since the eighties. ${ }^{8}$ Depending on the likelihood of repayment of their obligations, each rated sovereign is assigned a specific rating category over a scale mapping from AAA (i.e. the highest credit quality) to D (i.e. default). Either plus (+) or minus (-) signs are added to further refine the rating, thus, leading to a rating system that consists of twenty-four grades of risk.

Given the scope of the paper, we group sovereigns into two broad categories. Specifically, according with Fitch Ratings Inc.'s conventions (Fitch, 2017), sovereign borrowers are assigned to: (i) the Investment-grade category, if their obligations are rated BBB- or higher, thereby, indicating relatively low to moderate credit risk; and (ii) the Speculative-grade category, if they issue bonds with a credit rating $\mathrm{BB}+$ or below, thus, signalling either a higher level of risk or that a default has occurred (or it is likely to occur). We construct both categories of risk using both local currency- and foreign currency-denominated debt ratings with the objective of checking whether the gap between the two ratings affects the results of our analysis. ${ }^{9,} 10$

Then, we organize annual observations in spells, where a spell denoted by Dur_rank represents the number of consecutive years that a sovereign is assigned the Speculative-grade or the Investment-grade category.

Even though CRAs' methodologies have become more transparent since the Global Financial Crisis (GFC), they are proprietary. That is, sovereign rating decisions

\footnotetext{
${ }^{8}$ While estimation methodologies differ across CRAs, S\&P ratings are mostly based on the default probability (Baum et al., 2016). By contrast, Fitch's ratings rely both on the forward-looking default probability and the expected recovery rate, which is a more comprehensive set of proxy variables (Elkhoury, 2008). For this reason, misleading results may emerge when different agencies' ratings data are pooled together (Alsakka and ap Gwilym, 2013). Additionally, Löffler (2005) notes that there is a tension between accuracy and stability of ratings, and rating actions are inherently "sticky" (Posch, 2011). Indeed, Fitch tends to assign more value to the stability of sovereign ratings than S\&P, which implies that ratings of the latter are more volatile than those of the former (Alsakka and ap Gwilym, 2012). Without lack of generality in tracking ratings accuracy, our duration analysis framework captures well their stability which is especially relevant from a welfare perspective. This justifies the reliance on Fitch ratings data, which makes empirical findings less vulnerable to the presence of countries that would, otherwise, have had frequent credit rating changes (as in the case of other rating agencies data).

${ }^{9}$ As documented in Fitch (2017, p. 17), the local currency ratings are assigned based on the sovereign's ability to meet its obligations regardless of the currency of denomination of such obligations and in the absence of transfer and convertibility (T\&C) restrictions. As for foreign currency-denominated debt, ratings take into account the profile of the sovereign entity that is required to fulfil such financial obligations, as well as the government's willingness to impose restrictions on the conversion of local currency to foreign currency or the transfer of foreign currency to residents and non-residents (T\&C risk).

${ }^{10}$ The rationale behind the use of both domestic and foreign currency ratings is that the former is often higher than the latter reflecting the presumed greater ability and willingness of sovereigns to service debt denominated in their own currency. As Packer (2003) highlights, while many sovereigns can print money to meet domestic currency obligations, it must generate foreign exchange to repay foreign currency debts.
} 
can embed not only the (objective) assessment of macroeconomic, fiscal and government quality fundamentals but also some (subjective) judgement. In this context, the identification of a specific 'formula' that combines different macroeconomic and public finance factors and assigns them to a specific rating class may be complicated for two main reasons. First, subjective judgment by rating committee experts can play a role on rating outcomes. Second, the relative importance that CRAs attach to each potential factor may be time-varying (Kiff et al., 2010).

Concerning the first argument, the empirical evidence is not consensual. Indeed, some authors find that actual ratings are typically higher than warranted by economic fundamentals (Ferri et al., 1999; Mora, 2006); others show that observed ratings are lower than model-based predicted ratings (Gartner et al., 2011; Vernazza and Nielsen, 2015); and some others emphasise the alignment of ratings with economic fundamentals (Bruha et al., 2017). Additionally, most of the differences between actual and predicted ratings can be matched with the occurrence of crisis episodes. Thus, if anything, judgement only rarely explains sovereign ratings, with key (observable) factors - that our paper considers - largely driving CRAs' decision making process. And if judgement contributes to sovereign outcomes at a particular in time, it is likely to have barely any impact on the length of sovereign rating cycle phases, as the effect would be smoothed and would die out over the entire spell duration.

As for the second motive, the relatively small number of (investment- and speculative-grade) spells does not allow us to perform a sub-sample analysis where we can empirically investigate if the relative weight of alternative factors has changed or not over time. Nevertheless, our paper uses a selection of standard variables that the empirical literature on the topic has previously considered while exploring the factors behind sovereign rating developments (Cantor and Packer, 1996; Hu et al., 2002; Broto and Molina, 2016). The existing works have typically confirmed the importance of such variables (Afonso et al., 2011; Gartner et al., 2011; Gaillard, 2012). And they have concluded that their influence remained largely unchanged over time (Monfort and Mulder, 2000; Bissoondoyal-Bheenick, 2005; Afonso et al. 2007). Consequently, CRAs decision frameworks display a large degree of stability over the time dimension.

Against this background and as the second objective of the paper is to identify the main variables affecting the length of sovereign rating phases, we consider the following set of macroeconomic, fiscal and institutional factors: 
- Macroeconomic indicators, which track the country's economic performance, namely: (i) the inflation rate; (ii) the real GDP growth; and (iii) the trade balance (as percentage of GDP).

- Fiscal variables, which account for the ability of the government to service its debt, including: (iv) the budget balance to GDP ratio; and (v) the public debt to GDP ratio.

- Governance quality indicator, which covers six broad dimensions, such as: a) Control of Corruption; b) Government Effectiveness; c) Political Stability and Absence of Violence; d) Regulatory Quality; e) Rule of Law; and f) Voice and Accountability. By aggregating all six indicators, we construct a composite index (labelled as 'Quality of Governance'), which summarises the strength of institutional quality.

- An OECD dummy variable, which takes the value of one if a country is an OECD member, and zero otherwise. This allows us to test whether sovereign credit phases are longer (or shorter) in advanced countries than in emerging countries.

All macroeconomic and fiscal variables are retrieved from the World Economic Outlook (WEO) of the International Monetary Fund (IMF). Governance quality indicators are gathered from the World Bank's Worldwide Governance Indicators (WGI). Each indicator ranges from -2.5 to 2.5 , with higher values denoting a higher quality in a specific field of governance (Kaufmann et al., 2010).

We remark that, even though the original dataset consists of annual data for 130 countries until 2017, the presence of missing values for fiscal variables and the limited WGI coverage (which is confined to the period of 1996-2016) reduce the number of usable observations. This - together with the awareness that duration models are computationally demanding -, explains why we opt for a parsimonious model specification that privileges the use of a "core" set explanatory variables. ${ }^{11}$

\footnotetext{
${ }^{11}$ In our setup, data truncation is not recommended for two main reasons. First, by limiting the values of the variables above or below certain thresholds, we exclude (ex-ante) the possibility that all control variables' observations laying outside the bounds (i.e. those corresponding to a given percentile of the distribution) might explain the upper and lower tales of the distribution of the dependent variable (in our case, these correspond to the longest and shortest spells, respectively). Second, although truncation can help to exclude potential outliers from the analysis, it also leads to a reduction of the number of usable data points. This negatively impinges on statistical inference, making it less precise and reliable. Despite this, we have also performed econometric experiments where we truncate data at the 5th and 95th percentiles, that is, we consider the distribution of each independent variable and exclude from the estimation all the observations that can be labelled as "outliers". Our main empirical findings remain
} 
For local currency-denominated debt, we identify 13 spells of speculative-grade rating phases, which vary in length from one year to 21 years, thereby, generating 566 annual observations for our discrete-time duration analysis. Concerning foreign currency-denominated debt, we distinguish 28 spells of speculative-grade rating phases, which vary in length from one year to 22 years, thus, generating 690 annual observations. The mean duration of speculative-grade rating phases is about seven years for both domestic and foreign currency-denominated debt.

Regarding investment-grade rating phases, we identify 19 spells (or 1273 annual observations) for local currency-denominated debt, and 20 spells (or 1260 annual observations) for foreign currency-denominated debt. Investment-grade rating phases have an average duration of around 10.5 years, with the length ranging between one and 48 years. $^{12}$

\section{Empirical Findings}

In this section, we report results of the cloglog models as defined by equations (4)-(5). In practice, we estimate the model $\ln ] / \ln \left(1 / P_{i t}\right)_{-} ? \chi-q \ln t-\bullet^{\prime} \mathbf{x}_{i t}$, where $t=$ Dur_rank measures the duration of a sovereigns rating phase and its coefficient $q$ allows us to test for the presence of duration dependence. As demonstrated in Section 3, $q=p-1 \Leftrightarrow p=q+1$, where $p$ is the duration dependence parameter.

\subsection{The phase of speculative-grade}

Table 1 summarises the main results from the estimation of discrete-time Cloglog duration models applied to the speculative-grade phase. We start by looking at local currency-denominated debt. In column 1, we present estimates from a very basic model which only includes time-effects (not reported for the sake of space) and the OECD dummy variable. Then, we assess the role played by a vector of time-varying

unchanged even though the number of observations is substantially smaller compared to the full sample. This is close in spirit to the works of Sichel (1991) and Castro (2010, 2013), who show that, in this type of framework, results are not sensitive to the choice of the minimum observable duration. For brevity, these results are not reported in the paper, but they are available from the authors upon request.

${ }^{12} \mathrm{We}$ remark that the sum of observations, sum of spells and average durations are not necessarily the same for local currency- and foreign currency-denominated debt, because for some countries and years there are no ratings for either one or the other or both types of bonds. This means that the sum of observations for local currency-denominated debt (i.e. $566+1273=1839$ annual observations) is not necessarily equal to the sum of observations for foreign currency-denominated debt (i.e. $690+1260=1950$ annual observations). For the same reason, the total number of spells for local currency-denominated debt (i.e. $13+19=32$ spells) is not strictly the same as the total number of spells for foreign currencydenominated debt (i.e. $28+20=48$ spells). 
control variables as described in Section $4 .{ }^{13}$ Specifically, we first control for the importance of macroeconomic indicators (columns 2-3); then, we include fiscal variables in the model (columns 4-5); and, finally, we enlarge the model specification to account for governance quality (column 6).

We note that, regardless of the model specification, the coefficient associated with the natural logarithm of the variable Dur_rank (LnDur_rank) is always positive (i.e. $q>0$ ) and statistically significant. This implies that the estimate of the duration dependence parameter $(p=q+1)$ is statistically greater than 1 (positive duration dependence) and, therefore, the likelihood of a speculative-grade phase ending increases as it becomes "older". This evidence can be interpreted as supporting the view that, for speculative-rated sovereigns, building up the reputation as a good borrower can be thought as a gradual (sometimes, long-lasting) process.

Regarding the role played by quantitative control variables, we find that favourable economic performance significantly reduces the length of time spent by a sovereign in a speculative-grade phase. Specifically, a fall in inflation, a rise in GDP growth and an improvement of the trade balance are key for sovereigns to exit such phase. For instance, a one percentage point rise in GDP growth increases the likelihood of speculative-grade ratings phase ending by between $12.5 \%$ and $18.9 \%$. These results corroborate the view that sound macroeconomic conditions increase a country's ability to service its local-currency commitments and favour an upgrade of its credit risk rating.

Moreover, our findings indicate that the quality of governance matters: a one point rise in the composite index of governance quality boosts the hazard rate of a speculative-grade ratings phase ending by close to $25 \%{ }^{14}$

Finally, we note that the coefficient associated with the OECD dummy variable is statistically significant in most of the cases, which suggests that the length of

\footnotetext{
${ }^{13}$ All control variables enter the model specifications in contemporaneous terms. As our analysis is based on low-frequency (i.e. annual) data, the odds for a potential lag in the response of CRAs to changes in the macroeconomic, fiscal and institutional environment are low. Indeed, this would be more likely to occur in the case of quarterly data. Nevertheless, we also estimated alternative model specifications where we consider the lagged values of explanatory variables among the set of regressors. While the majority of coefficients associated with these lagged regressors is not statistically significant, those linked with contemporaneous regressors remain significant and their point estimates are also very close to those reported in the paper. Thus, the empirical evidence does not corroborate the existence of a lagged response of the duration of rating phases to the control variables included in the analysis. For brevity, these results are not reported in the paper, but they are available from the authors upon request.

${ }^{14}$ In particular, a positive perception of the quality of public services (as measured by the government effectiveness) and greater capability of the government to formulate and implement sound policies and regulations (as proxied by regulatory quality) are the most important qualitative aspects that speed up the end of a speculative-grade phase. For brevity, we do not report these results in the paper, but they are available from the authors upon request.
} 
speculative rating phases for debt denominated in domestic currency is shorter for OECD countries than for non-OECD countries.

Columns 7-12 of Table 1 point to sovereigns being rated differently depending on whether their ratings are based on the ability to meet domestic or foreign currencydenominated debt obligations (Packer, 2003). In general, the empirical findings confirm the presence of positive duration dependence, but this is less significant than for local currency-denominated debt. Thus, speculative rating phases based on foreign currencydenominated debt tend to be less sensitive to the passage of time than those based on domestic currency-denominated debt. This result supports the idea that sovereigns' ability and willingness to meet financial obligations denominated in their own currency is greater than in the case of debt denominated in foreign currency (Packer, 2003). Consequently, as time goes by, the probability of a speculative-grade phase ending is more (less) significantly affected for debt denominated in domestic (foreign) currency.

Looking at other explanatory variables, we note that higher public debt, more inflation and trade balance deterioration undermine the ability of sovereigns to meet their obligations denominated in foreign currency. Therefore, such macroeconomic developments lead to longer speculative-grade phases. For example, a one percentage point increase in the debt-to-GDP ratio is associated with a fall in the odds of a speculative-grade ratings phase of between $2 \%$ and 5\%. Interestingly, GDP growth is not statistically significant. This finding is consistent with speculative ratings reflecting the existence of structural problems that prevent domestic authorities to speed up the transition to an investment grade by means of good economic performance.

We also find that institutional quality impacts positively the probability that a speculative-grade phase ends, with the effect being even more important for foreign currency-denominated debt than that found for debt denominated in domestic currency. Indeed, in the case of foreign currency-denominated debt, a one point rise in the composite index of governance quality increases the probability of a speculative-grade ratings phase ending by, approximately, $39 \%{ }^{15}$

Finally, the OECD dummy variable is significant in the majority of model specifications, which indicates that, for foreign currency-denominated debt, the duration of speculative-grade phases is shorter in advanced economies than in emerging markets.

\footnotetext{
${ }^{15}$ Government effectiveness and regulatory quality improvements are especially relevant for shortening the length of the speculative-grade phase, thus, promoting the transition to an investment-grade phase. These results are not reported in the paper, but they are available from the authors upon request.
} 
[ Insert Table 1 here. ]

\subsection{The phase of investment-grade}

The empirical findings for the duration of the investment-grade phase are presented in Table 2. For local currency-denominated debt (columns 1-6), the evidence in favour of duration dependence in the investment-grade phase is, from a statistical view point, weak. Indeed, despite the fact that the sign of the coefficient associated with the variable LnDur_rank is always negative (which can be interpreted as a signal of negative duration dependence, as $p=q+1<1$ ), this variable is either insignificant or only significant at the $10 \%$ level. This result suggests that, once a sovereign's reputation as an excellent borrower has solidified, it generally remains unchanged as time goes by. Contrasting this finding with the one for the speculative-grade phase, we can conclude that higher sovereign ratings exhibit greater stability than lower sovereign ratings.

In what concerns the significance of control variables, we find that, improvements in economic growth and sounder fiscal positions (as reflected by lower public debt-to-GDP ratio and higher fiscal budget balance-to-GDP ratio) reduce the probability of investment-grade phase ending. For example, a one percentage point rise in the fiscal surplus (expressed in percentage of GDP) reduces the hazard rate of an investment-grade phase ending by between $22.1 \%$ and $27.1 \%$.

Contrary to the speculative-grade phase, the role of governance quality is rather limited. That is, compared to the duration of speculative-grade spells, the length of the investment-grade phase seems less sensitive to the quality of governance. ${ }^{16}$ The sign and statistical significance of the OECD dummy variable aligns with this interpretation: being part of OECD group is associated with longer investment-grade phases.

Regarding foreign currency-denominated debt (columns 7-12), the results are broadly similar to those obtained for local currency debt ratings. However, two major differences emerge. First, trade balance (as percentage of GDP) is now statistically significant. Its coefficient is negative, which shows that an improvement in net exports prolongs the duration of investment-grade phases. This is consistent with the evidence that persistent trade deficits are normally associated with growth in foreign indebtedness levels, which can ultimately undermine the creditworthiness of "net exporting"

\footnotetext{
${ }^{16}$ Only improvements in the control of corruption and political stability appear to significantly contribute to longer investment-grade spells. This is in line with the view that investment-grade rated sovereigns are, generally, developed economies with strong macroeconomic performance and stable fiscal policies. For brevity, we do not report these results in the paper, but they are available from the authors upon request.
} 
countries. Second, among the set of fiscal variables, we note that the government budget balance (as percentage of GDP) outweighs the statistical significance of the public debtto-GDP ratio. Thus, the consolidation of the public finances increases the so-called "fiscal space", thus, providing the necessary resources to meet their financial obligations.

[ Insert Table 2 here. ]

\section{Sensitivity Analysis}

In this Section, we evaluate the robustness of our results through the lens of two main econometric exercises. ${ }^{17}$ First, we provide evidence for "top-rated" sovereigns. Second, we consider non-monotonic hazard functions.

\subsection{The "high-grade" rating phase}

In Section 5.2., we did not find a clear support for the presence of duration dependence in investment-grade rating phases. Nevertheless, the coefficient associated with the variable LnDur_rank was always negative (regardless of the model specification used in the analysis) and, in six out of twelve specifications, it was also significant (albeit only at the 10\% level). Thus, this evidence can (weakly) signal a (latent) negative duration dependence. In particular, for top-rated sovereigns, rating agencies may be less prone to downgrade their ratings as time goes by.

\footnotetext{
${ }^{17} \mathrm{We}$ also assess the sensitivity of our baseline results to the inclusion of additional control variables. More specifically, we add - one at time - the following regressors (or their first lags) to the set of explanatory variables: (i) the actual rating assigned at the end of each year, which corresponds to one of the twenty-four grades of risk in a scale ranging between 0 (in the case of a restricted default) and 24 (for AAA-rated sovereign bonds); (ii) a dummy variable that takes the value of one if there is a rating change between the end of the previous year and the end of the current year, and zero otherwise; and (iii) the number of rating changes that occurred in each year based on information about rating announcements. As CRAs may change ratings in waves as a consequence of common global factors, we also expand the set of control variables to account for: (i) the Chicago Board Options Exchange (CBOE) Volatility Index (VIX), which is a proxy for global risk aversion and uncertainty; and (ii) the world GDP growth rate, which is obtained from the World Development Indicators (WDI) of the World Bank.

We find that rating upgrades are more likely to affect the length of speculative-grade phases in the case of foreign-currency denominated debt than local currency denominated debt, where the impact tends to be more gradual in time. Additionally: (i) when a rating change takes place in the previous year, speculative-grade phases tend to be shorter; and (ii) the larger the number of rating changes observed in the previous period, the higher the probability that foreign currency-denominated sovereign debt ratings will transit to an investment-grade. In what concerns the investment-grade phase and local currency ratings, none of the additional explanatory variables is significant, except for world GDP growth and the dummy variable for the occurrence of a rating change. Similarly, for foreign currency ratings, only the lagged term of the actual rating and the world GDP growth rate are significant.
}

For brevity, results are not reported in the paper, but they are available from the authors upon request. 
To empirically explore this possibility, we perform an assessment of the determinants of the duration of investment-grade spells for sovereigns with an exceptionally strong capacity to meet their financial commitments. More specifically, we focus on sovereigns whose domestic currency- and foreign currency-denominated debt is rated by Fitch as AA- or higher over the entire sample period.

We include all these sovereigns in a category labelled as "high-grade", and investigate whether the likelihood of exiting this rating class changes as time passes by, that is, we evaluate the presence of duration dependence therein. We expect that the longer the permanence in this "top" rating category, the lower the probability of a downgrade and the longer the duration of the "high-grade" rating phase.

We identify 16 spells of high-grade rating phases for local currencydenominated debt, which generate 667 observations. These spells have an average duration of 11 years. We also identify 12 spells of high-grade rating phases for foreign currency-denominated debt, thus, generating 610 observations. These spells' average duration is 11.6 years. Finally, high-grade rating phases have a duration ranging between one and 48 years for both domestic and foreign currency-denominated debt.

The empirical results associated with the duration analysis on high-grade rating phases are presented in Table 3. In columns 1-6, we report the estimates of the duration model based on domestic currency ratings, while columns 7-12 summarise the findings for foreign currency ratings.

We find that the variable LnDur_rank is significant and the sign of its coefficient is always negative, that is, $p=q+1<1$, which corroborates the presence of negative duration dependence. Thus, the likelihood of a "high-grade" phase ending declines with the passage of time, in line with the consolidation of the borrower's strong reputation.

This evidence is stronger when sovereigns' creditworthiness is evaluated using domestic currency ratings. Interestingly, the length of the "high-grade" rating phase is less sensitive to economic factors than the duration of the investment-grade phase.

Yet, fiscal conditions continue to play a very important role, with fiscal surpluses significantly prolonging the duration of "high-grade" spells. This effect is especially pronounced in the case of debt denominated in foreign currency: a one percentage point rise in the government budget balance-to-GDP ratio is associated with a fall in the likelihood of a "high-grade" rating phase of between $15.8 \%$ and $20.2 \%$ in the case of domestic currency-denominated debt, and of between $29.5 \%$ and $32.7 \%$ in the case of foreign currency-denominated debt. 
[ Insert Table 3 here. ]

\subsection{Non-monotonic hazard functions}

The Weibull model imposes a restrictive constraint on the shape of the hazard function, since its continuous distribution - as well as its discrete-time equivalent - can only rise or decline in a monotonic way. Yet, this pattern may not be an adequate configuration. Consequently, we also consider non-monotonic specifications for the hazard function, which are more flexible and allow us to evaluate the presence of nonlinearity over time. More specifically, we test some quadratic- and cubic-in-time specifications for the hazard function in the cloglog framework. ${ }^{18}$

Table 4 report results for speculative- (columns 1-4) and investment-grade phases (columns 5-8), respectively. While columns 1-2 and 5-6 summarise the findings for domestic currency-denominated debt ratings, columns 3-4 and 7-8 present results for foreign currency ratings.

We find some non-monotonic (quadratic) behaviour for speculative-grade phases (columns 1 and 3). Specifically, the likelihood of a speculative-grade phase ending increases over time, as the coefficient of Dur_rank is positive. However, this pattern is observed only until a certain duration: the coefficient of Dur_rank ${ }^{2}$ is negative, so the likelihood of a speculative-grade phase ending starts falling at some point in time. In the specific case of domestic currency-denominated debt ratings, the hazard rate increases until around 11 years of duration, and decreases afterwards (i.e., for longer speculative-grade phases). ${ }^{19}$ Thus, sovereigns that do not leave the speculative-grade phase within (roughly) a decade face the prospects of a prolonged low-rating spell, as chances of exiting that phase are reduced after ten years. This provides a more granular characterisation of the hazard function vis-à-vis the monotonically increasing hazard rate estimates obtained in Section 5.1.. Finally, we do not find any support for cubic specifications (columns 2 and 4).

\footnotetext{
${ }^{18}$ The estimation of specifications like the piecewise-dummies (that imposes no constraints on the shape of the hazard function) could clarify potential doubts about the hazard configuration. However, the hazard's shape might "zig-zag" over time. Therefore, we follow Beck et al. (1998) and use "natural cubic splines" (i.e. a vector of spline basis variables that are cubic polynomials of Dur rank) to smooth out the coefficients and the hazard function based on them. Estimates using two and three natural cubic splines of the hazard function corroborate the findings associated with the polynomial-in time specifications. These results are not reported in the paper, but they are available from the authors upon request.

${ }^{19}$ The estimate of the duration that maximises the hazard obtained from the respective function considering the estimated coefficients obtained in column 1 of Table 4 and evaluating all regressors at their means is: $P_{i t}=1-\exp \left(-\exp \left(1.075^{*}\right.\right.$ Dur_rank-0.052*Dur_rank $\left.\left.{ }^{2}-10.353\right)\right)$, where $\hat{\bullet}^{\prime} \mathbf{\mathbf { x }}=-10.353$.
} 
As for the investment-grade phase, the evidence of a non-monotonic behaviour is not robust. In one hand, when we allow for a cubic specification (columns 6 and 8), linear and quadratic coefficients are significant in the case of local currency ratings but not for foreign currency-denominated debt, and the coefficient on the cubic term is not statistically significant. This would suggest some support for a quadratic hazard rate. On the other hand, when we test for a quadratic hazard function (columns 5 and 7), none of the coefficients is significant. These findings are in line with the lack of duration dependence uncovered in Section 5.2., when we assumed a monotonic hazard function.

Finally, it should be noted that the empirical evidence concerning macroeconomic indicators, fiscal variables and governance quality is both quantitatively and qualitatively similar to that reported for the Weibull model specification.

[ Insert Table 4 here. ]

\section{Conclusions}

We use data on sovereign ratings for a sample of 130 developed and emerging countries to understand the dynamics of investment-grade and speculative-grade phases. Compared to the existing literature, the two major novel aspects of the paper are: $(i)$ to explore the presence of duration dependence in such phases; and (ii) to investigate the determinants of their length using discrete-time Weibull duration models.

The empirical findings indicate that the speculative-grade rating phase displays positive duration dependence, while the investment-grade rating phase is not duration dependent. This is consistent with greater stability of sovereign ratings at top of the distribution of the bond credit tier than at the bottom of the distribution.

Conditioning the duration of both phases on a set of control variables, we find that lower inflation, stronger growth and sounder fiscal positions shorten (prolong) the speculative- (investment-) grade phase. Moreover, improvements in the quality of governance reduce the length of speculative-grade rating phases. Finally, we show that, for local currency-denominated debt, investment-grade phases are longer in OECD countries than in non-OECD countries; and, for foreign currency-denominated debt, speculative-grade phases are shorter in OECD countries compared to non-OECD countries. These results are robust to the consideration of non-monotonic hazard functions or the inclusion of additional control variables.

From a policy perspective, our empirical findings have important implications. First, the evidence on duration dependence confirms that time plays an key role not only 
for understanding the duration of sovereign rating phases, but also for assessing the transition across different sovereign rating classes. Thus, building up a good reputation as a borrower is naturally a gradual process for speculative-rated sovereign bonds in the sense that it requires time until the upgrade to the investment-class takes place. By contrast, investment-rated sovereign bonds appear to be more immune to changes in their rating tiers even as time goes by. Interestingly, sovereign issuers rated AA- or higher - i.e. borrowers with a very strong or extremely strong capacity to meet their financial commitments - typically display longer investment-grade spells.

Second, domestic and foreign currency-denominated debt ratings behave in a way that promotes domestic bond market development (Packer, 2003). This helps governments to shield against volatile foreign currency-denominated investment flows.

Third, the analysis on the determinants of the duration of sovereign rating phases reveals that growth-friendly economic policies coupled with fiscal discipline and strong quality of governance can shorten (prolong) the speculative- (investment-) grade rating phases. Therefore, such policies can be welfare-improving.

\section{References}

Agnello, L., Castro, V., and R.M. Sousa, 2012. How does fiscal policy react to wealth composition and asset prices? Journal of Macroeconomics, 34(3), 874-890.

Afonso, A., Gomes, P., and P. Rother, 2007. What 'hides' behind sovereign debt ratings? European Central Bank, ECB Working Paper no. 711.

Afonso, A., Gomes, P., and P. Rother, 2011. Short and long run determinants of sovereign debt credit ratings. International Journal of Finance and Economics, 16(1), 1-15.

Agnello, L., Castro, V., and R.M. Sousa, 2013. What determines the duration of a fiscal consolidation program? Journal of International Money and Finance, 37, 113-134.

Agnello, L., Castro, V., and R.M. Sousa, 2015a. Booms, busts and normal times in the housing market. Journal of Business \& Economic Statistics, 33(1), 25-45.

Agnello, L., Castro, V., and R.M. Sousa, 2015b. Is fiscal fatigue a threat to consolidation programmes? Environment and Planning C: Government and Policy, 33, 765-779.

Agnello, L., Castro, V., and R.M. Sousa, 2018a. The legacy and the tyranny of time: Exit and re-entry of sovereigns to international capital markets. Journal of Money Credit and Banking, forthcoming. Available at: https://doi.org/10.1111/jmcb.12474.

Agnello, L., Castro, V., and R.M. Sousa, 2018b. Economic activity, credit market conditions, and the housing market. Macroeconomic Dynamics, 22(7), 1769-1789.

Agnello, L., Castro, V., and R.M. Sousa, 2018c. Financial markets' shutdown and reaccess. Economic Inquiry, 56(1), 562-571. 
Aizenman, J., Pinto, B., and V. Sushko, 2013. Financial sector ups and downs and the real sector in the open economy: up by the stairs, down by the parachute. Emerging Markets Review. 16, 1-30.

Allison, P., 1982. Discrete-time methods for the analysis of event histories. Sociological Methodology, 13, 61-98.

Alsakka, R., and O. ap Gwilym, 2010. Leads and lags in sovereign credit ratings. Journal of Banking and Finance, 34, 2614-2626.

Alsakka, R., and O. ap Gwilym, 2012. Foreign exchange market reactions to sovereign credit news. Journal of International Money Finance, 31(4), 845-864.

Alsakka, R., and O. ap Gwilym, 2013. Rating agencies' signals during the European sovereign debt crisis: Market impact and spillovers. Journal of Economic Behavior \& Organization, 85, 144-162.

Baum, C.F., Schäfer, D., and A. Stephan, 2016. Credit rating agency downgrades and the Eurozone sovereign debt crises. Journal of Financial Stability, 24, 117-131.

Beck, N., Katz, J., and R. Tucker, 1998. Taking time seriously: time-series-crosssection analysis with a binary dependent variable. American Journal of Political Science, 42, 1260-1288.

Bissoondoyal-Bheenick, E. , 2005. An analysis of the determinants of sovereign ratings. Global Finance Journal, 15(3), 251-280.

Broto, C., and L. Molina, 2016. Sovereign ratings and their asymmetric response to fundamentals. Journal of Economic Behavior \& Organization 130, 206-224.

Bruha, J., Karber, M., Pierluigi, B., and R. Setzer, 2017. Understanding sovereign rating movements in euro area countries. European Central Bank, ECB Working Paper no. 2011.

Cantor, R., and F. Packer, 1996. Determinants and impact of sovereign credit ratings. Federal Reserve Bank N. Y. Economic Policy Review, October, 1-15.

Castro, V., 2010. The duration of economic expansions and recessions: More than duration dependence. Journal of Macroeconomics, 32, 347-365.

Castro, V., 2013. The duration of business cycle expansions and contractions: Are there change-points in duration dependence? Empirical Economics, 44, 511-544.

Castro, V., and R. Martins, 2013. Is there duration dependence in Portuguese local governments tenure? European Journal of Political Economy, 31, 29-39.Castro, V., and R.M. Sousa, 2012. How do central banks react to wealth composition and asset prices? Economic Modelling, 29(3), 641-653.

Duggar, E., Emery, K., Gates, D., Paulo, S., Lemay, Y., and P. Cailleteau, 2009. Emerging market corporate and sub-sovereign defaults and sovereign crises: Perspectives on country risk. Moody's Investors Service, February.

Elkhoury, M., 2008. Credit rating agencies and their potential impact on developing countries. United Nations Conference on Trade and Development, UNCTAD Discussion Paper no. 186.

Ferri, G., Liu, L.G., and J.E. Stiglitz, 1999. The procyclical role of rating agencies: evidence from the East Asian crisis. Economic Notes, 28, 335-355. 
Fitch, 2017. Ratings Definitions. Technical Document available at: https://www.fitchratings.com/site/definitions.

Gaillard, N. , 2012. A century of sovereign ratings. Springer-Verlag: New York, US.

Gartner, M., Griesbach, B., and F. Jung, 2011. PIGS or lambs? The European sovereign debt crisis and the role of rating agencies. International Advances in Economic Research, 17(3), 288-299.

Granville, B., and S.K. Mallick, 2009. Monetary and financial stability in the euro area: Pro-cyclicality versus Trade-off. Journal of International Financial Markets, Institutions \& Money, 19(4), 662-674.

Hu, Y.T., Kiesel, R., and W. Perraudin, 2002. The estimation of transition matrices for sovereign credit ratings. Journal of Banking and Finance, 26, 1383-1406.

Jalles, J.T., 2015. Is there a long-run relationship between unemployment and productivity? Comparative Economic Research, 18(2). Available at: https://doi.org/10.1515/cer-2015-0012.

Jalles, J.T., 2018. What determines the share of non-resident public debt ownership? Evidence from Euro Area countries. Annals of Finance, 14(3), 379-414.

Jawadi, F., Namouri, H., and Z. Ftiti (2018). An analysis of the effect of investor sentiment in a heterogeneous switching transition model for G7 stock markets. Journal of Economic Dynamics and Control, 91, 469-484.

Jenkins, S. 1995. Easy estimation methods for discrete-time duration models. Oxford Bulletin of Economics and Statistics 57, 129-138.

Jenkins, S., 2005. Survival Analysis. Mimeo. University of Essex. (https://www.iser.essex.ac.uk/files/teaching/stephenj/ec968/pdfs/ec9681notesv6.pdf)

Juttner, J.D., and J. McCarthy, 1998. Modelling a rating crisis. Macquarie University, unpublished manuscript.

Kaminsky, G., and S. Schmukler, 2002. Emerging markets instability: Do sovereign ratings affect country risk and stock return. World Bank Economic Review, 16, 171195.

Kaufmann, D., Kraay, A., and M. Mastruzzi, 2010. The Worldwide Governance Indicators: Methodology and analytical issues. World Bank Policy Research Working Paper no. 5430, September.

Kiefer, N., 1988. Economic duration data and hazard functions. Journal of Economic Literature, 26, 646-679.

Kiff, J., Holland, A., Kisser, M., Nowak, S., Saab, S., Schumacher, L., van der Hoorn, H., and A.-M. Westin, 2010. The uses and abuses of sovereign credit ratings. Global Financial Stability Report, October. International Monetary Fund: Washington DC, US.

Löffler, G., 2005. Avoiding the rating bounce: why rating agencies are slow to react to new information. Journal of Economic Behavior \& Organization, 56, 365-381.

Lunde, A., and A. Timmermann, 2004. Duration dependence in stock prices: An analysis of bull and bear markets. Journal of Business \& Economic Statistics, 22(3), 253-273. 
Mallick, S.K., and M. Mohsin, 2010. On the real effects of inflation in open economies: theory and empirics. Empirical Economics, 39(3), 643-673.

Mallick, S.K., and M. Mohsin, 2016. Macroeconomic effects of inflationary shocks with durable and non-durable consumption. Open Economies Review, 27(5), 895921.

Mallick, S.K., and M. Mostak Ahamed, 2017a. Does regulatory forbearance matter for financial stability? Evidence from creditors' perspective. Journal of Financial Stability, 28, 163-180.

Mallick, S.K., and M. Mostak Ahamed, 2017b. House of restructured assets: How do they affect bank risk in an emerging market? Journal of International Financial Markets, Institutions and Money, 47, 1-14.

Mallick, S.K., and M. Mostak Ahamed, 2017c. Is financial inclusion good for bank stability? International evidence. Journal of Economic Behavior \& Organization, forthcoming. Available at: https://doi.org/ 10.1016/j.jebo.2017.07.027.

Michaelides, A., Milidonis, A., Nishiotis, G., and P. Papakyriakou, 2015. The adverse effects of systematic leakage ahead of official sovereign debt rating announcements. Journal of Financial Economics, 116(3), 536-547.

Mora, N., 2006. Sovereign credit ratings: guilty beyond reasonable doubt? Journal of Banking and Finance 30, 2041-2062.

Monfort, B., and C. Mulder, 2000. Using credit ratings for capital requirements on lending to emerging market economies - Possible impact of a new Basel accord. International Monetary Fund, IMF Technical Report no. 69.

Mora, N., 2006. Sovereign credit ratings: guilty beyond reasonable doubt? Journal of Banking and Finance 30, 2041-2062.

Packer, F., 2003. Mind the gap: domestic versus foreign currency sovereign ratings. BIS Quarterly Review, September.

Posch, P.N., 2011. Time to change. Rating changes and policy implications. Journal of Economic Behavior \& Organization, 80, 641-656.

Prentice, R., and L. Gloeckler, 1978. Regression analysis of grouped survival data with application to the breast cancer data. Biometrics, 34, 57-67.

Rodríguez, G., 2010. Parametric survival models. Princeton University, Working Paper.

Sichel, D., 1991. Business cycle duration dependence: A parametric approach. Review of Economics and Statistics, 73, 254-260.

Sy, A., 2002. Emerging market bond spreads and sovereign credit ratings: Reconciling market views with economic fundamentals. Emerging Markets Review 3, 380-408.

Vernazza, D.R., and E.F. Nielson, 2015. The damaging bias of sovereign ratings. Economic Notes, 44(2), 362-408.

\section{APPENDIX}

\section{List of Tables}


Table 1. Duration of the speculative-grade phase: Local and foreign currency ratings.

\begin{tabular}{|c|c|c|c|c|c|c|c|c|c|c|c|c|}
\hline \multirow{2}{*}{ VARIABLES } & \multirow{2}{*}{\multicolumn{6}{|c|}{ Local currency }} & \multicolumn{6}{|c|}{ Foreign currency } \\
\hline & (1) & & & & (5) & (6) & (7) & $(8)$ & & (10) & (11) & (12) \\
\hline LnDur_rank & $\begin{array}{c}0.903^{* *} \\
(0.455)\end{array}$ & $\begin{array}{l}0.942^{* *} \\
(0.447)\end{array}$ & $\begin{array}{l}0.869^{*} \\
(0.499)\end{array}$ & $\begin{array}{l}1.231^{* *} \\
(0.530)\end{array}$ & $\begin{array}{c}1.658^{* * *} \\
(0.501)\end{array}$ & $\begin{array}{c}1.509^{* * *} \\
(0.514)\end{array}$ & $\begin{array}{c}0.156 \\
(0.245)\end{array}$ & $\begin{array}{c}0.280 \\
(0.247)\end{array}$ & $\begin{array}{c}0.293 \\
(0.234)\end{array}$ & $\begin{array}{l}0.523^{* *} \\
(0.252)\end{array}$ & $\begin{array}{c}0.336 \\
(0.285)\end{array}$ & $\begin{array}{l}0.636^{*} \\
(0.357)\end{array}$ \\
\hline Inflation & & $-0.062^{*}$ & $-0.089 * *$ & $-0.113 * * *$ & $-0.108 * * *$ & $-0.122 * * *$ & & $-0.056 * *$ & $-0.055 * *$ & $-0.068^{* *}$ & $-0.087^{* *}$ & $-0.110^{* * *}$ \\
\hline & & $(0.034)$ & $(0.044)$ & $(0.036)$ & $(0.036)$ & $(0.041)$ & & $(0.027)$ & $(0.025)$ & $(0.031)$ & $(0.035)$ & $(0.041)$ \\
\hline GDP growth & & & $\begin{array}{c}0.121^{* * *} \\
(0.044)\end{array}$ & $\begin{array}{c}0.130^{* * *} \\
(0.049)\end{array}$ & $\begin{array}{l}0.118^{* *} \\
(0.052)\end{array}$ & $\begin{array}{c}0.145^{* * *} \\
(0.054)\end{array}$ & & & $\begin{array}{l}-0.018 \\
(0.048)\end{array}$ & $\begin{array}{l}-0.011 \\
(0.043)\end{array}$ & $\begin{array}{l}-0.036 \\
(0.045)\end{array}$ & $\begin{array}{l}-0.014 \\
(0.046)\end{array}$ \\
\hline Trade balance (\% GDP) & & & & $0.122 * * *$ & $0.132^{* * * *}$ & $0.157^{* * * *}$ & & & & $0.095^{* * * *}$ & $0.097 * * *$ & $0.126^{* * *}$ \\
\hline Government balance (\% GDP) & & & & $(0.029)$ & $\begin{array}{l}(0.032) \\
-0.024\end{array}$ & $\begin{array}{l}(0.036) \\
-0.001\end{array}$ & & & & & $\begin{array}{l}(0.026) \\
-0.036\end{array}$ & $\begin{array}{c}(0.032) \\
0.001\end{array}$ \\
\hline 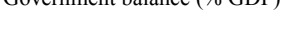 & & & & & & $(0.07$ & & & & & & \\
\hline Government debt (\% GDP) & & & & & -0.002 & -0.010 & & & & & $-0.020^{* *}$ & $-0.039 * * *$ \\
\hline & & & & & $(0.008)$ & $(0.012)$ & & & & & $(0.008)$ & $(0.013)$ \\
\hline Quality of governance & & & & & & $\begin{array}{l}0.218^{*} \\
(0.121)\end{array}$ & & & & & & $\begin{array}{c}0.328^{* * *} \\
(0.108)\end{array}$ \\
\hline OECD & 0.78 & $\begin{array}{ll}0.846^{*} \\
\end{array}$ & $1.112 * *$ & 1.16 & $1.332 * *$ & 1.1 & $1.345^{* * *}$ & $1.586^{* * *}$ & $1.563^{* * *}$ & $1.389^{* * * *}$ & $1.830^{* * *}$ & $1.281^{* * *}$ \\
\hline & & & & & & & & & & & & \\
\hline Constant & $-6.243 * * * *$ & $-5.832^{* * * *}$ & $-6.057^{* * * *}$ & $-6.060^{* * *}$ & $-6.987 * * *$ & $-6.059^{* * * *}$ & $-3.940^{* * * *}$ & $-3.842^{* * * *}$ & $-3.818^{* * * *}$ & $-3.756 * * *$ & $-2.3577^{* *}$ & $-1.890^{*}$ \\
\hline & $\frac{51.2517}{544}$ & 492 & $\frac{1(.203)}{492}$ & $\frac{1}{4.251)}$ & $\frac{(1.09)}{450}$ & (1..10) & $\frac{(0.090)}{690}$ & $\frac{(0.000)}{631}$ & $\frac{(0.094)}{631}$ & $\frac{(0.092)}{603}$ & $\frac{(0.980)}{551}$ & $\frac{(1.143)}{550}$ \\
\hline $\mathrm{Ti}$ & T & $\mathrm{Y}$ & $\mathrm{y}$ & $\mathrm{Y}$ & $\mathrm{Y}$ & 100 & $\mathrm{Y}$ & & & & & $\mathrm{y}$ \\
\hline & M & 13 & 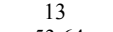 & 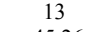 & & 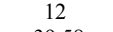 & 28 & 28 & 20 & 20 & 20 & 20. \\
\hline $\mathrm{LO}$ & -58.73 & -56.38 & -53.64 & -45.26 & -41.24 & -39.58 & -112.2 & -105.9 & -105.8 & -95.31 & 84.23 & 72.58 \\
\hline
\end{tabular}

Notes: Robust standard errors (clustered by country) in parentheses. Significance level at which the null hypothesis is rejected: ${ }^{*}$ significant at $10 \%,{ }^{* *}$ significant at $5 \%,{ }^{* * *}$ significant at $1 \%$. $N_{-}$sis the number of censored observations. LogL is the log-likelihood of the estimated model.

Table 2. Duration of the investment-grade phase: Local and foreign currency ratings.

\begin{tabular}{|c|c|c|c|c|c|c|c|c|c|c|c|c|}
\hline \multirow[b]{2}{*}{ VARIABLES } & \multicolumn{6}{|c|}{ Local currency } & \multicolumn{6}{|c|}{ Foreign currency } \\
\hline & (1) & (2) & (3) & (4) & (5) & (6) & (7) & (8) & & $(10)$ & (11) & (12) \\
\hline LnDur_rank & & & & -0.421 & $-0.761^{*}$ & & & & -0.094 & & 0.174 & \\
\hline LiIDtir_tank & $(0.224)$ & $(0.271)$ & $(0.282)$ & $(0.361)$ & $(0.422)$ & $(0.451)$ & $(0.297)$ & $(0.301)$ & $(0.265)$ & $(0.327)$ & $(0.311)$ & $(0.369)$ \\
\hline Inflation & & 0.075 & 0.060 & 0.044 & 0.039 & 0.012 & & $0.147 * * *$ & $0.135 * * *$ & $0.135^{* *}$ & $0.139^{* *}$ & 0.096 \\
\hline & & $(0.052)$ & $(0.054)$ & $(0.068)$ & $(0.101)$ & $(0.100)$ & & $(0.056)$ & $(0.050)$ & $(0.056)$ & $(0.064)$ & $(0.080)$ \\
\hline GDP growth & & & $\begin{array}{l}-0.168 * * * \\
0.040 *\end{array}$ & $-0.168 * * *$ & $\begin{array}{l}-0.175 * * * \\
0.052\end{array}$ & $\begin{array}{l}-0.213 * * * \\
(0.058 *\end{array}$ & & & $\begin{array}{l}-0.214 * * * * \\
-0.047\end{array}$ & $\begin{array}{l}-0.254 * * * \\
(0.058 *\end{array}$ & $-0.228 * * *$ & $-0.242^{* * *}$ \\
\hline Trade balance (\% GDP) & & & & $\begin{array}{l}(0.043) \\
-0.044^{*}\end{array}$ & -0.047 & $\begin{array}{l}(0.058) \\
-0.042\end{array}$ & & & & $-0.084 * *$ & $-0.079 * *$ & $-0.081 * *$ \\
\hline & & & & $(0.025)$ & $(0.035)$ & $(0.036)$ & & & & $(0.035)$ & $(0.033)$ & $(0.034)$ \\
\hline Government balance (\% GDP) & & & & & $-0.236 * * *$ & $-0.228 * * *$ & & & & & $-0.165 * * *$ & $-0.169 * * *$ \\
\hline Government debt (\% GDP) & & & & & $(0.042)$ & $(0.042)$ & & & & & $(0.048)$ & $(0.049)$ \\
\hline Government debt (\% GDP) & & & & & $\begin{array}{c}0.026^{2 * * * 4} \\
(0.009)\end{array}$ & $\begin{array}{c}0.0266^{* * * x} \\
(0.009)\end{array}$ & & & & & $\begin{array}{l}0.001 \\
(0.008)\end{array}$ & $\begin{array}{l}.0001 \\
(0.008)\end{array}$ \\
\hline Quality of governance & & & & & & $\begin{array}{l}-0.166^{*} \\
(0.091)\end{array}$ & & & & & & $\begin{array}{l}-0.132 \\
(0.112)\end{array}$ \\
\hline OECD & $-2.324 * * *$ & $-2.113^{* *}$ & $-2.127^{* * * *}$ & $-2.047 * *$ & $-4.032^{* *}$ & $-3.181^{* *}$ & 0.046 & 0.238 & -0.094 & 0.168 & 0.174 & 0.013 \\
\hline & $(0.80$ & $(0.82)-x)$ & $(0.8$ & $(0.87$ & $(1.5 \%$ & $(1.5$ & $(0.297)$ & $(0.3$ & & & & $(0.369)$ \\
\hline Constant & $\begin{array}{c}-13.711 * * * \\
(1263)\end{array}$ & $\begin{array}{l}-13.988 * * * \\
(1419)\end{array}$ & $-1.844 * * *$ & $-1.884 * *$ & $-3.375^{* * * *}$ & $-2.885 * *$ & & $0.147^{7 * * *}$ & $0.135 * * *$ & $0.135^{* *}$ & & 0.096 \\
\hline & $(1$. & & $(0.670)$ & $(0.873)$ & $(1.094)$ & $(1.172)$ & & & $(0$. & & & $(0.080)$ \\
\hline $\begin{array}{l}\text { Observations } \\
\text { Time effects }\end{array}$ & 1,263 & 1,187 & 1,166 & 1,110 & 924 & 924 & $\begin{array}{l}-1.038^{*} \\
-0594)\end{array}$ & $\begin{array}{c}-0.809 \\
(0.588\end{array}$ & & & -0.981 & \\
\hline $\mathrm{Ns}$ & $\begin{array}{c}Y \\
19\end{array}$ & Y & Y & Y & Y & Y & $-15.840 * * *$ & $\begin{aligned} & (0.588) \\
-17.439 * * & \end{aligned}$ & $(0.566)$ & $(0.695)$ & $(0.841)$ & $(1.224)$ \\
\hline & 19 & 18 & 18 & 688 & 14 & 14 & 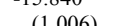 & -1.43011 & $(0689)$ & $5.5817)$ & $-4.310^{2}$ & $3.711 \%$ \\
\hline
\end{tabular}

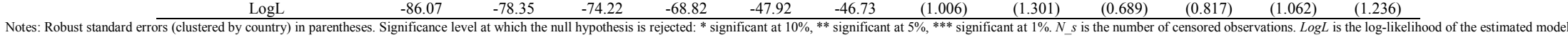


Table 3. Duration of the "high-grade" phase: Local and foreign currency ratings

\begin{tabular}{|c|c|c|c|c|c|c|c|c|c|c|c|c|}
\hline & \multicolumn{6}{|c|}{ Local currency } & \multicolumn{6}{|c|}{ Foreign currency } \\
\hline & (1) & (2) & (3) & (4) & (5) & (6) & (7) & (8) & & (10) & (11) & (12) \\
\hline \multirow[t]{2}{*}{ LnDur_rank } & $-0.531 * *$ & $-0.443^{* *}$ & $-0.541^{* * *}$ & $-0.617^{* *}$ & $-0.632^{*}$ & $-0.636^{*}$ & -0.415 & -0.344 & $-0.470^{*}$ & -0.580 & $-1.311^{*}$ & $-1.710^{* * * *}$ \\
\hline & $(0.228)$ & & & $(0.255)$ & $(0.349)$ & $(0.335)$ & $(0.270)$ & $(0.274)$ & $(0.268)$ & $(0.356)$ & $(0.786)$ & $(0.596)$ \\
\hline \multirow{2}{*}{ Inflation } & & 0.052 & 0.083 & 0.015 & 0.084 & 0.040 & & 0.151 & 0.203 & 0.065 & -0.084 & -0.039 \\
\hline & & & $(0.174)$ & $(0.173)$ & $(0.223)$ & $(0.215)$ & & $(0.246)$ & $(0.222)$ & $(0.210)$ & $(0.375)$ & $(0.558)$ \\
\hline \multirow{2}{*}{ GDP growth } & & & & $-0.192^{*}$ & -0.104 & -0.110 & & & $-0.242 * * *$ & $-0.392 * * *$ & $-0.240^{* *}$ & $-0.291 * *$ \\
\hline & & & $(0.110)$ & $(0.099)$ & $(0.122)$ & $(0.106)$ & & & $(0.087)$ & $(0.117)$ & $(0.107)$ & $(0.137)$ \\
\hline Trade balance (\% GDP) & & & & $-0.088^{*}$ & $\begin{array}{l}-0.099 \\
(0.074)\end{array}$ & $\begin{array}{l}-0.128 \\
(0.091)\end{array}$ & & & & $-0.212^{* * *}$ & $-0.273^{*}$ & $\begin{array}{l}-0.381 * * \\
(0.169)\end{array}$ \\
\hline Government balance (\% GDP) & & & & $(0.049)$ & $-0.226 * * *$ & $-0.172^{* * * *}$ & & & & & $-0.396 * * *$ & $-0.350 * * *$ \\
\hline \multirow{2}{*}{ Government debt (\% GDP) } & & & & & $\begin{array}{l}(0.055) \\
-0.003\end{array}$ & $\begin{array}{l}(0.055) \\
-0.001\end{array}$ & & & & & $\begin{array}{c}(0.107) \\
0.001\end{array}$ & $\begin{array}{c}(0.084) \\
0.008\end{array}$ \\
\hline & & & & & $(0.011)$ & $(0.011)$ & & & & & $(0.009)$ & $(0.016)$ \\
\hline Quality of governance & & & & & & $\begin{array}{l}-0.253^{*} \\
(0.144)\end{array}$ & & & & & & $\begin{array}{l}-0.548 \\
(0.345)\end{array}$ \\
\hline \multirow[t]{2}{*}{ OECD } & 0.194 & 0.104 & -0.033 & -0.480 & -0.513 & 0.427 & -0.395 & -0.432 & -0.451 & $-1.130^{*}$ & 0.004 & $1.808^{* * *}$ \\
\hline & $(0$. & $(0.600)$ & $(0.6$ & $(0.71$ & $(0.976)$ & $(1.268)$ & $(0.665)$ & $(0.794)$ & & $(0.671)$ & $(1.5)$ & $(0.917)$ \\
\hline \multirow[t]{2}{*}{ Constant } & $-16.238 * * *$ & $-15.600 * * *$ & -1.40 & -0.288 & -1.187 & 0.01 & $-16.636 * * *$ & $-17.921 * * *$ & $-1.666^{*}$ & 0.271 & -0.799 & 1.905 \\
\hline & $(1.119)$ & $(1.85$ & $(0.949)$ & $(1.059)$ & $(1.178)$ & $(1$. & $(1.1$ & $(2.379)$ & $(0.994)$ & & $(1.211)$ & $(1.505)$ \\
\hline Observations & 657 & 618 & 605 & 569 & 553 & 534 & 600 & 557 & 547 & 528 & 514 & 481 \\
\hline Time effects & Y & Y & $\mathrm{Y}$ & $\mathrm{Y}$ & $\mathrm{y}$ & $\mathrm{Y}$ & $\mathrm{Y}$ & $\mathrm{Y}$ & $\mathrm{Y}$ & $\mathrm{Y}$ & $\mathrm{Y}$ & $\mathrm{Y}$ \\
\hline N_s & 16 & 16 & 16 & 15 & 15 & 15 & 12 & 12 & 12 & 11 & 10 & 10 \\
\hline $\log \mathrm{L}$ & -71.90 & -70.69 & -69.53 & -61.93 & -55.74 & -52.55 & -56.53 & -54.74 & -52.41 & -39.22 & -29.82 & -24.29 \\
\hline
\end{tabular}

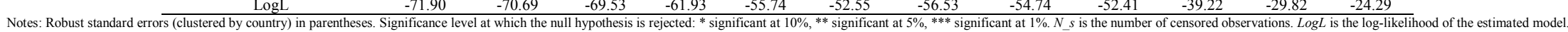

\begin{tabular}{|c|c|c|c|c|c|c|c|c|}
\hline \multirow{3}{*}{$\frac{\text { VARIABLES }}{\text { Dur_rank } \| \text { Spline } 1}$} & \multirow{2}{*}{\multicolumn{2}{|c|}{$\begin{array}{l}\text { Speculative-grade: Local currency } \\
\text { (1) }\end{array}$}} & \multirow{2}{*}{\multicolumn{2}{|c|}{$\begin{array}{l}\text { Speculative-grade: Foreign currency } \\
\text { (3) }\end{array}$}} & \multirow{2}{*}{\multicolumn{2}{|c|}{$\begin{array}{l}\text { Investment-grade: Local currency } \\
(6)\end{array}$}} & \multirow{2}{*}{\multicolumn{2}{|c|}{ Investment-grade: Foreign currency }} \\
\hline & & & & & & & & \\
\hline & $1.075^{* * *}$ & 0.667 & $0.392^{* * *}$ & 0.368 & -0.139 & $-1.243^{* *}$ & 0.136 & -0.759 \\
\hline \multirow{3}{*}{ Dur_rank ${ }^{2}||$ Spline2 } & $(0.395)$ & $(0.796)$ & $(0.201)$ & $(0.505)$ & $(0.127)$ & $(0.518)$ & $(0.099)$ & $(0.485)$ \\
\hline & $-0.052^{* *}$ & -0.001 & $-0.017^{*}$ & -0.014 & 0.004 & $0.094 *$ & -0.004 & $0.093^{*}$ \\
\hline & $(0.022)$ & $(0.104)$ & & $(0.070)$ & & $(0.057)$ & & $(0.056)$ \\
\hline Dur_rank $^{3}||$ Spline3 & & $\begin{array}{l}-0.002 \\
(0.004)\end{array}$ & & $\begin{array}{l}-0.000 \\
(0.003)\end{array}$ & & $\begin{array}{c}-0.002 \\
(0.002)\end{array}$ & & $\begin{array}{l}-0.000^{*} \\
(0.02)\end{array}$ \\
\hline \multirow{2}{*}{ Inflation } & $-0.197 * *$ & $-0.204 * *$ & $-0.126 * * *$ & $-0.127^{* *}$ & 0.013 & 0.025 & $0.140^{* *}$ & 0.086 \\
\hline & $(0.090)$ & $(0.103)$ & $(0.045)$ & $(0.051)$ & $(0.100)$ & $(0.115)$ & $(0.063)$ & $(0.079)$ \\
\hline \multirow[t]{2}{*}{ GDP growth } & $0.158 * *$ & $0.162 * *$ & -0.018 & -0.017 & $-0.198 * * *$ & $-0.238 * * *$ & $-0.224 * * *$ & $-0.240^{* * *}$ \\
\hline & $(0.063)$ & $(0.067)$ & $(0.049)$ & $(0.050)$ & $(0.058)$ & $(0.075)$ & $(0.066)$ & $(0.066)$ \\
\hline \multirow[t]{2}{*}{ Trade balance (\% GDP) } & $0.173^{* * *}$ & $0.174 * * *$ & $0.125 * * *$ & $0.125^{* * * *}$ & -0.043 & $-0.088 * *$ & $-0.080 * *$ & $-0.086^{* * *}$ \\
\hline & $(0.039)$ & $(0.042)$ & $(0.031)$ & $(0.031)$ & $(0.036)$ & $(0.040)$ & $(0.033)$ & $(0.032)$ \\
\hline \multirow[t]{2}{*}{ Government balance (\% GDP) } & -0.047 & -0.049 & -0.002 & -0.002 & $-0.220 * * *$ & $-0.294 * * *$ & $-0.160 * * *$ & $-0.148 * * *$ \\
\hline & $(0.116)$ & $(0.114)$ & $(0.048)$ & $(0.048)$ & $(0.044)$ & $(0.052)$ & $(0.049)$ & $(0.052)$ \\
\hline \multirow[t]{2}{*}{ Government debt (\% GDP) } & -0.016 & -0.016 & $-0.040^{* * * *}$ & $-0.040^{* * *}$ & $0.026^{* * * *}$ & $0.024^{* * * *}$ & 0.002 & 0.001 \\
\hline & & $(0.012)$ & $(0.013)$ & $(0.014)$ & $(0.009)$ & $(0.009)$ & $(0.008)$ & $(0.009)$ \\
\hline Quality of governance & $\begin{array}{l}0.283^{* *} \\
(0.112)\end{array}$ & $\begin{array}{c}0.285^{* *} \\
(0.114)\end{array}$ & $\begin{array}{c}0.337^{* * *} \\
(0.104)\end{array}$ & $\begin{array}{l}0.336^{* * * *} \\
(0.106)\end{array}$ & $\begin{array}{l}-0.166^{*} \\
(0.100)\end{array}$ & $\begin{array}{l}-0.259^{*} \\
(0.147)\end{array}$ & $\begin{array}{l}-0.162 \\
(0.120)\end{array}$ & $\begin{array}{l}-0.126 \\
(0.120)\end{array}$ \\
\hline \multirow{4}{*}{$\begin{array}{c}\text { OECD } \\
\text { Constant }\end{array}$} & 0.840 & 0.859 & $1.402 * * *$ & $1.401^{* * * *}$ & $-3.446^{*}$ & $-3.474^{*}$ & -0.968 & -0.681 \\
\hline & & $(0.874)$ & & $(0.538)$ & $(1.763)$ & $(1.793)$ & $(0.934)$ & $(1.251)$ \\
\hline & $-6.890^{* * *}$ & $-5.966 * * *$ & $-2.194^{*}$ & $-2.153^{*}$ & $-3.726^{* * *}$ & -1.329 & $-4.770^{* * * *}$ & -2.447 \\
\hline & $\begin{array}{c}-0.0302) \\
(1.822)\end{array}$ & $\begin{array}{r}-5.900 \\
(2.008) \\
\end{array}$ & $(1.240)$ & (1.167) & $(1.261)$ & $\begin{array}{l}-1.52) \\
(1.113) \\
\end{array}$ & $(1.069)$ & $\begin{array}{l}-2.499) \\
(1.499)\end{array}$ \\
\hline Constant & 450 & 450 & 550 & 550 & 924 & 924 & 991 & 991 \\
\hline Time effects & & $\mathrm{Y}$ & & & & & & \\
\hline $\mathrm{N} \_\mathrm{s}$ & 12 & 12 & 25 & 25 & 14 & 14 & 18 & 18 \\
\hline$J_{0}$ & -37.85 & -37.78 & -72.06 & -72.06 & -47.50 & -42.56 & -63.86 & 60.51 \\
\hline
\end{tabular}

